\title{
Failure of Exclusive Breastfeeding and Inadequate Frequency of Complementary Feeding as Predictors of Stunting
}

\author{
Giyawati Yulilania Okinarum ${ }^{1,2}$
}

1 Departmen Kebidanan Program Profesi, Fakultas Ilmu Kesehatan, Universitas Respati Yogyakarta

2 Quality Maternal and Newborn Care Research Alliance

\begin{tabular}{l}
\multicolumn{1}{c}{ Article Info } \\
\hline Article History: \\
Submitted: July $3^{\text {rd }}, 2021$ \\
Accepted: August $9^{\text {th }}, 2021$ \\
Published: August $31^{\text {st }}, 2021$ \\
Keywords: \\
Exclusive breastfeeding; \\
frequency of complementary \\
feeding; stunting
\end{tabular}

\section{PENDAHULUAN}

Dua masalah gizi terbesar di Indonesia adalah kekurangan gizi dan kelebihan gizi. Masalah kurang gizi kronis dalam bentuk anak pendek atau stunting merupakan masalah kekurangan gizi yang mendapat banyak perhatian utama [1]. Kekurangan gizi kronis memengaruhi panjang badan. Stunting didefinisikan sebaai Z-score <-2 SD

\begin{abstract}
In Indonesia, stunting is still a chronic nutritional problem. Many factors influence the prevalence of stunting, including a history of exclusive breastfeeding and the frequency of complementary feeding. The purpose of this study is to determine how much of an impact the exclusive breastfeeding and frequency of complementary feeding has on stunting. This observational analytic study was conducted from July to September 2019 using a case control approach. Samples of 80 children aged 12-24 months, with details of toddlers case group (stunting) and control (normal) 40 each, with inclusion criteria of birth weight and normal gestational age in Yogyakarta. Stratified random sampling was used for sampling. Filling out questionnaires and conducting interviews were used to collect data on characteristics, breastfeeding, and early complementary feeding. Nutritional status is calculated using height/age. Multivariate analysis by multiple logistical regression test revealed statistically significant correlations between stunting and non-exclusive breastfeeding (adjusted OR for exclusive breastfeeding 5,17; 95\% CI 1,87 to 14,31) as well as inadequate frequency of complementary feeding (adjusted OR 3,85; 95\% CI 1,32 to 11,18). This value implies that exclusive breastfeeding and adequate frequency of complementary feeding are the most dominant protecting factors against stunting. In children aged 12-24 months, the histories of non-exclusive breastfeeding and inadequate frequency of complementary feeding are significantly correlated with stunting.
\end{abstract}

untuk rasio tinggi badan terhadap usia (TB/U) atau rasio panjang badan terhadap usia (PB/U). Masa balita merupakan masa pertumbuhan dan perkembangan, berlangsung sangat progresif yang dapat menentukan kualitas anak di kemudian hari. Pada masa ini, kondisi kurang gizi sangat rawan dialami oleh para balita $[2,3]$.

Corresponding author:

Giyawati Yulilania Okinarum

gitaokinarum@respati.ac.id

Media Keperawatan Indonesia, Vol 4 No 3, August 2021

e-ISSN: 2615-1669

ISSN: 2722-2802

DOI: $\underline{10.26714 / \mathrm{mki} .4 .3 .2021 .182-190}$ 
Prevalensi balita pendek menjadi masalah kesehatan masyarakat jika prevalensinya $20 \%$ atau lebih. Sebanyak 165 juta (26\%) balita mengalami stunting di seluruh dunia. Indonesia termasuk dalam 5 negara dengan angka balita stunting tertinggi yaitu 7,5 juta balita [4]. Prevalensi balita pendek di Indonesia tertinggi dibandingkan Myanmar (35\%), Vietnam (23\%), Malaysia (17\%), Thailand (16\%) dan Singapura (4\%) [5]. Global Nutrition Report tahun 2014 menunjukkan Indonesia termasuk dalam 17 negara, di antara 117 negara, yang mempunyai tiga masalah gizi yaitu stunting, wasting, dan overweight pada balita [6].

Persentase status gizi balita pendek (pendek dan sangat pendek) di Indonesia adalah $37,2 \%$, yang terdiri dari 18\% sangat pendek dan 19,2\% pendek, artinya telah terjadi peningkatan sebanyak 1,6\% pada tahun $2010 \quad(35,6 \%) \quad[3,6]$. Persentase stunting di DIY tahun 2017 adalah 19,8\%, menurun dibanding tahun sebelumnya 2016 (21,84\%), tahun 2015 (20,56\%), dan tahun 2014 (22,1\%). Meski angka persentasenya di bawah yang ditetapkan WHO (20\%), namun kondisi ini cukup mengkhawatirkan, maka diperlukan berbagai tindakan baik untuk mengantisipasi maupun menangani kejadian anak stunting [7]. Persentase stunting di Kabupaten Sleman tahun 2019 adalah $11 \%$ meskipun di bawah $20 \%$ namun angka ini masih tergolong tinggi di Provinsi DIY dan perlu adanya perhatian khusus untuk mencapai target zero case di tahun 2025 [8], sehingga Bupati Sleman menyusun Peraturan Bupati mengenai upaya penanggulangan dan penurunan percepatan stunting di Sleman [9].

Stunting pada anak di bawah usia lima tahun memerlukan perhatian khusus karena efeknya menghambat perkembangan fisik dan mental. Stunting pada usia dini dapat meningkatkan risiko mortalitas dan morbiditas, serta postur tubuh yang kurang optimal saat dewasa. Balita yang mengalami stunting memiliki risiko terjadinya penurunan kemampuan intelektual, produktivitas, dan peningkatan risiko penyakit degeneratif seperti diabetes mellitus, stroke, obesitas, serta penyakit jantung di masa mendatang. Hal ini disebabkan oleh anak stunting yang cenderung lebih rentan terhadap penyakit infeksi, sehingga berisiko mengalami penurunan kualitas belajar di sekolah. Hal tersebut merupakan dampak bagi negara karena akan timbul masalah kesehatan dan ekonomi yang berakibat pada modal sumber daya manusia dan produktivitas [10-15].

Strategi global WHO/UNICEF tentang pemberian makanan pada bayi dan anak kecil merekomendasikan empat poin penting untuk mencapai pertumbuhan dan perkembangan yang optimal: inisiasi menyusu dini (IMD) pada 30 menit pertama kehidupan, pemberian ASI eksklusif selama 6 bulan pertama kehidupan, pemberian makanan pendamping ASI yang disertai dengan pemberian ASI pada usia 6-24 bulan, dan pemberian ASI terus menerus selama 2 tahun atau lebih $[16,17]$. Tumbuh kembang selama masa bayi membutuhkan nutrisi yang seimbang, karena sistem usus balita masih dalam proses pematangan. Studi sebelumnya menunjukkan bahwa kejadian stunting lebih tinggi pada kelompok non-ASI eksklusif [18]. ASI mengandung banyak faktor yang dapat memenuhi kebutuhan nutrisi bayi sesuai dengan usianya [19]. Selain itu, ASI juga mengandung zat imunologis yang dapat mencegah terjadinya infeksi pada bayi. Namun, data terakhir menunjukkan bahwa perilaku pemberian ASI eksklusif pada 6 bulan pertama kehidupan masih belum sesuai dengan rekomendasi $[16,17,20]$. Data WHO/UNICEF 2015 tentang Pemberian Makanan Bayi dan Anak menunjukkan bahwa hanya $39 \%$ bayi di negara berkembang yang menerima ASI eksklusif 0-5 bulan [16]. Oleh karena itu, kami bertujuan untuk mengetahui hubungan antara riwayat pemberian ASI dan frekuensi MPASI per hari yang tidak adekuat dengan kejadian stunting pada anak usia 2-5 tahun. 


\section{METODE}

Penelitian ini adalah analitik observasional yang dilakukan dengan pendekatan case control. Subjek penelitian adalah anak balita berusia 12-24 bulan sebanyak 80 sampel (kelompok kasus 40; kelompok kontrol 40) di Kabupaten Sleman. Periode penelitian dilakukan pada bulan Juli-September 2019. Kriteria inklusi adalah balita yang memiliki riwayat lahir dengan berat dan usia kehamilan normal. Sementara itu kriteria eksklusinya adalah jika terdapat keterbatasan dalam komunikasi, gangguan mental dan fisik, dan tinggi ibu kurang dari $150 \mathrm{~cm}$. Sampel akan secara otomatis menjadi drop out apabila pindah tempat tinggal dan menolak diwawancara saat pertengahan penelitian. Penelitian ini menggunakan stratified random sampling. Tahap pertama memilih Kecamatan di Kabupaten Sleman. Tahap kedua dipilih beberapa desa pada tiap kecamatan. Tahap terakhir adalah pengambilan sampel, dilakukan pada sampel yang hadir di posyandu pada hari peneliti datang.

Data yang diambil pada penelitian ini adalah data primer. Pengambilan data usia, jenis kelamin, dan tinggi badan balita dilakukan pertama kali. Kemudian wawancara pada ibu balita terkait ASI eksklusif dan MP-ASI. Wawancara dilakukan menggunakan kuesioner ASI eksklusif dan MP-ASI yang telah tervalidasi. Proses pengambilan data dilakukan oleh enumerator dengan basic nutrisionis yang telah dilatih terlebih dulu oleh peneliti. Analisis data menggunakan uji multivariat logistik berganda.

Data pengukuran usia jenis kelamin, dan tinggi badan balita yang terkumpul dianalisis dengan merujuk pada ketentuan WHO yaitu menghitung Z-Score atau menggunakan grafik pertumbuhan rujukan WHO. Berdasarkan Z-Score yang diperoleh dapat ditentukan status gizi seorang anak menurut tinggi badan per usia $(\mathrm{TB} / \mathrm{U})$ dengan klasifikasi yaitu sangat pendek apabila kurang dari -3, pendek apabila lebih dari -3 sampai kurang dari -2, dan normal apabila lebih dari -2 sampai dengan lebih dari 2. Klasifikasi sangat pendek dan pendek digabungkan menjadi pendek ketika menganalisis hubungan antara pemberian ASI eksklusif, MP-ASI, dan frekuensi MPASI per hari dengan anak stunting.

Pada variabel riwayat ASI eksklusif, kategorinya adalah non-ASI eksklusif dan ASI eksklusif. Dikatakan non-AS eksklusif jika bayi diberikan makanan buatan selain ASI, baik susu formula, bubur atau makanan lainnya sebelum bayi berusia enam bulan, baik diberikan secara kontinyu maupun diberikan sebagai makanan prelakteal (menyusui parsial) dan menyusui bayi tetapi pernah memberikan sedikit air atau minum berbasis air misalnya teh, sebagai makanan atau minuman prelakteal sebelum ASI keluar (menyusui predominan). Dikatakan ASI eksklusif jika pada usia 0-6 bulan hanya diberi ASI saja, tidak memberi bayi makanan atau minuman lain, termasuk air putih, selain menyusui, kecuali obatobatan dan vitamin. Sementara itu pada variabel MP-ASI dikategorikan menjadi dua yaitu MP-ASI dini (jika makanan pendamping diberikan pada usia $<6$ bulan) dan MP-ASI tepat waktu (apabila makanan pendamping diberikan tepat di usia 6 bulan). Pengkategorian dilakukan berdasarkan Pedoman Gizi Seimbang Kementerian Kesehatan RI 2014. Pada variabel frekuensi MPASI kategorinya tidak cukup dan cukup. Disebut tidak cukup jika diberi makan utama 2-3 kali per hari dan 1 porsi camilan, masuk kategori cukup jika diberi makan utama 3-4 kali per hari dengan tambahan 1-2 porsi camilan sehat.

Sebelum dilakukan pengambilan data di Posyandu, aspek legalitas tetap diperhatikan dengan adanya pembuatan surat etik sesuai dengan Komite Etik Fakultas Ilmu Kesehatan Universitas Respati Yogyakarta nomor: 307.3/FIKES/PL/IX/2019. 


\section{HASIL}

Responden berjumlah 80 anak usia 12-24 bulan yang tinggal di Kabupaten Sleman serta memiliki karakteristik yang dapat dilihat pada Tabel 1. Sebagian besar responden baik yang stunting maupun tidak, memiliki penghasilan keluarga di atas UMK Kota Yogyakarta (> Rp 1.903.500,00), memiliki berat badan lahir normal karena hanya $16,25 \%$ saja yang berat badan lahir rendah (BBLR), berjenis kelamin laki-laki, dan usia ibu saat hamil pada rentang 20-35 tahun. Pada kedua kelompok baik kasus maupun kontrol, rerata pekerjaan yang memiliki penghasilan keluarga di bawah UMR yaitu buruh, ojek online, dan kurir paket.

Secara statistik, tidak ada perbedaan signifikan antara penghasilan keluarga, riwayat berat badan lahir, usia ibu saat hamil, dan pekerjaan ibu antara kelompok kasus dan kontrol, sedangkan jenis kelamin anak memiliki perbedaan yang signifikan antara kelompok kasus dan kontrol $(p<0,05)$.

Pada kelompok kasus (stunting), sebagian besar tidak mendapatkan ASI eksklusif dan frekuensi pemberian MPASI tidak adekuat. Hal tersebut berbanding terbalik pada kelompok kontrol (normal/tidak stunting) yang berhasil ASI eksklusif dan frekuensi pemberian MPASI per hari yang cukup. Sementara itu, usia pengenalan MP-ASI sebagian besar terjadi pada usia 6 bulan (35\% dan 43,75\%) di kedua kelompok. Berdasarkan hasil analisis regresi logistik, riwayat pemberian ASI eksklusif dan frekuensi pemberian MP-ASI merupakan faktor risiko kejadian stunting. Keduanya memiliki hubungan yang bermakna terhadap kejadian stunting $(\mathrm{p}<0,05)$, hal tersebut ditunjukkan dalam tabel 2.

Analisis multivariat dilakukan dengan uji regresi logistik berganda menggunakan permodelan dengan memasukkan $p$ value $<0,25$ ke dalam tabel, lalu membandingkan nilai OR riwayat ASI eksklusif, frekuensi pemberian MP-ASI per hari, dan jenis kelamin anak dengan kejadian stunting. Model dibangun menggunakan metode enter yaitu secara manual ditentukan variabel lain yang akan dikeluarkan dari analisis yaitu variabel yang tidak memilki hubungan signifikan dengan kejadian stunting ( $p$ value $>0,05$ ) yang ditunjukkan pada tabel 3.

Variabel paling dominan memengaruhi kejadian stunting adalah riwayat ASI eksklusif yang dapat dilihat pada tabel 3 . Diperoleh hasil bahwa anak yang gagal dalam pemberian ASI eksklusif, maka memiliki risiko kejadian stunting sebesar 5,17 kali dibanding dengan anak yang berhasil dalam pemberian ASI eksklusif.

Model yang dipilih untuk memprediksi kejadian stunting adalah model 3 karena variabel lain yang tersisa antara lain riwayat pemberian ASI eksklusif (signifikan pada $\alpha=1 \%$ ), dan frekuensi MPASI per hari (signfikan pada $\alpha=5 \%$ ) memiliki pengaruh yang signifikan terhadap kejadian stunting. Model 3 menunjukkan bahwa riwayat pemberian ASI eksklusif dan frekuensi pemberian MPASI per hari pada anak mampu memprediksi kejadian stunting sebesar 31,4\% setelah mengendalikan jenis kelamin anak. Hal tersebut ditunjukkan dalam tabel 4. 
Tabel 1

Karakteristik Responden pada Kelompok Kasus (Stunting) dan Kontrol (Normal)

\begin{tabular}{|c|c|c|c|c|c|c|c|c|}
\hline \multirow{3}{*}{ Variabel } & \multicolumn{4}{|c|}{ Status Responden } & \multirow{2}{*}{\multicolumn{2}{|c|}{ Total }} & \multirow[b]{3}{*}{ OR $(95 \% \mathrm{CI})$} & \multirow[b]{3}{*}{$\mathrm{p}$} \\
\hline & \multicolumn{2}{|c|}{ Stunting } & \multicolumn{2}{|c|}{ Normal } & & & & \\
\hline & $\mathrm{f}$ & $\%$ & $\mathrm{f}$ & $\%$ & $\mathrm{f}$ & $\%$ & & \\
\hline \multicolumn{9}{|l|}{ Penghasilan keluarga } \\
\hline Di bawah UMK $(<1.903 .500)$ & 13 & 16,25 & 9 & 11,25 & 22 & 27,5 & $1,47(0,43-5,02)$ & 0,542 \\
\hline Di atas UMK (>1.903.500) & 27 & 33,75 & 31 & 38,75 & 58 & 72,5 & & \\
\hline \multicolumn{9}{|l|}{ Riwayat Berat badan lahir } \\
\hline BBLR & 7 & 8,75 & 6 & 7,5 & 13 & 16,25 & $0,92(0,19-4,42)$ & 0,922 \\
\hline Normal & 33 & 41,25 & 34 & 42,5 & 67 & 83,75 & & \\
\hline \multicolumn{9}{|l|}{ Usia ibu saat hamil } \\
\hline $20-35$ & 29 & 36,25 & 29 & 36,25 & 58 & 72,5 & $0,70(0,19-2,59)$ & 0,596 \\
\hline$>35$ & 11 & 13,75 & 11 & 13,75 & 22 & 27,5 & & \\
\hline \multicolumn{9}{|l|}{ Jenis kelamin anak } \\
\hline Laki-laki & 28 & 35 & 21 & 26,25 & 49 & 61,25 & $3,50(1,06-11,56)$ & $0,040^{*}$ \\
\hline Perempuan & 12 & 15 & 19 & 23,75 & 31 & 38,75 & & \\
\hline \multicolumn{9}{|l|}{ Pekerjaan ibu } \\
\hline Tidak bekerja & 26 & 32,5 & 30 & 37,5 & 56 & 70 & $0,53(0,17-1,70)$ & 0,288 \\
\hline Bekerja & 14 & 17,5 & 10 & 12,5 & 24 & 30 & & \\
\hline
\end{tabular}

Keterangan : *) signifkan

Tabel 2

Analisis Regresi Logistik Sederhana Riwayat Pemberian MP-ASI, Riwayat ASI Eksklusif, dan Frekuensi Pemberian MPASi per hari pada Kelompok Kasus (Stunting) dan Kontrol (Normal)

\begin{tabular}{lcccc}
\hline \multicolumn{1}{c}{ Variabel } & \multicolumn{2}{c}{ Status Anak } & $\mathrm{p}$ & OR (95\% CI) \\
\cline { 2 - 3 } & $\begin{array}{c}\text { Stunting } \\
(\%)\end{array}$ & $\begin{array}{c}\text { Normal } \\
(\%)\end{array}$ & & \\
\hline Riwayat Pemberian MPASI & $12(15)$ & $5(6,25)$ & 0,356 & $0,46(0,08-2,40)$ \\
$\begin{array}{l}\text { Dini (<6 bulan) } \\
\text { Tepat waktu (6 bulan) }\end{array}$ & $28(35)$ & $35(43,75)$ & & \\
Riwayat ASI eksklusif & $27(33,75)$ & $10(12,5)$ & $0,004^{*}$ & $7,32(1,89-28,30)$ \\
Tidak & $13(16,25)$ & $30(37,5)$ & & \\
Ya & & & & \\
Frekuensi Pemberian MP-ASI per hari & & & & \\
Tidak Cukup & $22(27,5)$ & $8(10)$ & $0,004^{*}$ & $5,86(1,74-19,74)$ \\
Cukup & $18(22,5)$ & $32(40)$ & & \\
\hline
\end{tabular}

Keterangan : *) signifikan

Tabel 3

Analisis Regresi Logistik Berganda Riwayat ASI Eksklusif, Frekuensi Pemberian MPASI per hari, dan Jenis Kelamin Anak Terhadap Kejadian Stunting

\begin{tabular}{lccc}
\hline \multicolumn{1}{c}{ Variabel } & Model 1 & Model 2 & Model 3 \\
& OR (CI 95\%) & OR (CI 95\%) & OR (CI 95\%) \\
\hline Riwayat ASI eksklusif & $0,18(0,06-0,53)^{*}$ & $6,23(2,35-16,51)^{*}$ & $5,17(1,87-14,31)^{*}$ \\
Ya & 1 & 1 & 1 \\
Tidak & & & \\
Frekuensi Pemberian MP-ASI per & $0,22(0,07-0,67)^{*}$ & $4,89(1,81-13,21)^{*}$ & $3,85(1,32-11,18)^{*}$ \\
hari & 1 & 1 & 1 \\
Tidak Cukup & & - & - \\
Cukup & $0,33(0,11-1,00)^{*}$ & & \\
Jenis kelamin anak & 1 & & \\
Laki-laki & & & \\
Perempuan & & &
\end{tabular}


Tabel 4

Model Regresi Logistik Riwayat ASI Eksklusif, Frekuensi Pemberian MPASI per hari, dan Jenis Kelamin Anak Terhadap Kejadian Stunting

\begin{tabular}{|c|c|c|c|c|c|c|}
\hline \multirow[t]{2}{*}{ Variabel } & \multicolumn{2}{|c|}{ Model 1} & \multicolumn{2}{|c|}{ Model 2} & \multicolumn{2}{|c|}{ Model 3} \\
\hline & $\mathrm{p}$ & B (S.E.) & $\mathrm{p}$ & B (S.E.) & $\mathrm{p}$ & B (S.E.) \\
\hline $\begin{array}{l}\text { Riwayat ASI eksklusif } \\
\text { Ya } \\
\text { Tidak }\end{array}$ & $0,002^{* * *}$ & $\begin{array}{c}-1,701 \\
(0,540)\end{array}$ & $0,000^{* * *}$ & $1,829(0,497)$ & $0,002^{* * *}$ & $1,644(0,519)$ \\
\hline $\begin{array}{l}\text { Frekuensi Pemberian } \\
\text { MP-ASI per hari } \\
\text { Tidak Cukup } \\
\text { Cukup }\end{array}$ & $0,008^{* *}$ & $\begin{array}{c}-1,528 \\
(0,577)\end{array}$ & $0,002^{* *}$ & $1,587(0,507)$ & $0,013^{* *}$ & $1,348(0,544)$ \\
\hline $\begin{array}{l}\text { Jenis kelamin anak } \\
\text { Laki-laki } \\
\text { Perempuan }\end{array}$ & $0,050^{*}$ & $\begin{array}{c}-1,118 \\
(0,571)\end{array}$ & - & - & - & - \\
\hline $\mathrm{N}$ & & & & 80 & & 80 \\
\hline Nagelkerke $R^{2}$ & & & & 0,228 & & 0,314 \\
\hline
\end{tabular}

Keterangan : ${ }^{* * *}$ ) signifikan pada $\alpha=1 \%$

**) signifikan pada $\alpha=5 \%$

*) signifikan pada $\alpha=5 \%$

\section{PEMBAHASAN}

Periode kritis pada pertumbuhan tinggi badan adalah dua tahun pertama kehidupan anak, sehingga pemberian ASI eksklusif dinilai dari lahir hingga 6 bulan dan makanan pendamping ASI (MP-ASI) dinilai dari lahir hingga 2 tahun [21]. Pada penelitian ini, anak dengan jenis kelamin laki-laki yang mengalami stunting sebesar $61,25 \%$ (Tabel 1). Studi penelitian lain menunjukkan bahwa anak laki-laki lebih sering mengalami stunting 1,27 kali lipat dibanding dengan anak perempuan [22]. Data yang dirilis di negara berkembang lainnya, yaitu India, melaporkan bahwa risiko relatif kejadian stunting pada anak lak-laki sebesar 1,65 kali jika dibandingkan pada anak perempuan [23]. Hal tersebut berbanding terbalik dengan studi lainnya yang menunjukkan bahwa risiko relatif IUGR sebesar 1,19 kali lebih besar pada anak perempuan daripada anak laki-laki yang bahkan kondisi IUGR yang dialami berdampak pada kejadian stunting di kemudian hari [24].

Data yang kami analisis menunjukkan bahwa terdapat hubungan antara kegagalan pemberian ASI eksklusif terhadap kejadian stunting $(\mathrm{p}<0,05)$. Anak yang tidak diberi ASI eksklusif berpotensi 5,17 kali lipat lebih besar mengalami stunting dibandingkan anak yang mendapatkan ASI eksklusif (Tabel 2). Hal tersebut sejalan dengan penelitian lainnya yang menyebutkan bahwa anak dengan pola menyusui non ASI eksklusif mempunyai peluang lebih tinggi menjadi stunting dibandingkan ASI eksklusif $[25,26]$, bahkan bayi yang tidak diberi ASI eksklusif secara langsung dapat memengaruhi kejadian stunting [27], proporsi stunting lebih banyak pada bayi usia 6-9 bulan yang non-ASI eksklusif [18], dan anak usia 2-5 tahun berpotensi stuting jika gagal diberi ASI eksklusif [28]. Intervensi yang berfokus pada nutrisi optimal selama tahap pemberian ASI eksklusif dan MP-ASI secara substansial mengurangi kejadian stunting secara cukup tinggi [29]. Pengaruh ASI yang besar terhadap status gizi anak, membuat WHO merekomendasikan agar menerapkan intervensi peningkatan pemberian ASI selama 6 bulan pertama sebagai salah satu langkah untuk mencapai WHO Global Nutrition Targets 2025 mengenai penurunan jumlah stunting pada anak di bawah lima tahun [30].

Studi kami melaporkan pula bahwa terdapat hubungan yang bermakna pada pemberian frekuensi MP-ASI yang tidak adekuat terhadap kejadian stunting $(p<0,05)$. Anak dengan frekuensi pemberian MP-ASI yang tidak adekuat, akan 
berisiko 3,85 kali lipat mengalami stunting (Tabel 2). Praktik pemberian makan dapat memengaruhi kejadian stunting pada anak. Perilaku yang kurang benar dalam pemilihan dan frekuensi pemberian makan pada anak merupakan faktor yang menyebabkan kurang gizi dan stunting [31]. Frekuensi makan yang hanya 2-3 kali per hari menjadi sebuah permasalahan karena berdasarkan wawancara yang dilakukan pada penelitian ini, makanan yang dikonsumsi oleh responden hanya nasi dengan sayur saja, dengan ikan, atau bahkan hanya nasi dan kuah soto saja. Hasil penelitian menunjukkan frekuensi pemberian MP-ASI termasuk dalam kategori kurang pada kelompok kasus (27,5\%). Berdasarkan hasil survei konsumsi pangan menggunakan dietary history, menunjukkan bahwa kebiasaan makan umumnya hanya 2-3 kali sehari dan hanya terdiri dari dua jenis, yaitu makanan pokok dan sayur atau makanan pokok dan sumber protein saja, bahkan tidak sedikit yang hanya makanan pokok dan kuah sayur. Frekuensi minimal pemberian makan pada balita juga perlu diperhatikan. Sebuah penelitian yang dilakukan di Nigeria menunjukkan bahwa balita yang tidak mendapatkan makanan sesuai dengan frekuensi minimal pemberian makan maka memiliki peluang mengalami stunting yang lebih besar $(20,1 \%)$ dibandingkan yang mendapatkan makanan dengan frekuensi minimal pemberian makan [32]. Pemberian MP-ASI dengan adekuat dengan gizi yang cukup itupun akan memengaruhi pada kondisi stunting nantinya, seperti pada sebuah studi yang menyebutkan zat gizi mikro yaitu vitamin A dan zink berpengaruh pada proses pertumbuhan linier [33]. Temuan lainnya di Malawi melaporkan bahwa $62 \%$ anak-anak yang stunting memiliki konsentrasi serum yang lebih rendah dari seluruh asam amino esensial (triptofan, isoleusin, leusin, valin, metionin, treonin, histidin, fenilalanin, lisin) dibandingkan dengan anak-anak yang tidak stunting $(\mathrm{p}<0,05)$, artinya anak-anak dengan risiko stunting yang tinggi mungkin tidak menerima asupan makanan yang cukup dari asam amino esensial dan kolin, nutrisi penting untuk sintesis sphingolipin dan gliserofosfolipid [34].

\section{SIMPULAN}

Berdasarkan hasil penelitian ini dapat disimpulkan bahwa terdapat hubungan antara ketidakberhasilan dalam pemberian ASI eksklusif dan frekuensi MP-ASI per hari yang tidak adekuat terhadap kejadian stunting $(\mathrm{p}<0,05)$. Anak yang tidak diberi ASI eksklusif berpotensi 5,17 kali lipat lebih besar mengalami stunting dibanding dengan anak yang mendapatkan ASI eksklusif dan anak yang frekuensi MP-ASI per hari diberikan secara tidak adekuat akan berisiko 3,85 kali lipat mengalami stunting. Riwayat pemberian ASI eksklusif merupakan faktor paling dominan yang memengaruhi kejadian stunting.

\section{UCAPAN TERIMAKASIH}

Ucapan terima kasih disampaikan kepada Kementerian Riset dan Teknologi Pendidikan Tinggi (Kemenristekdikti) yang telah membantu pendanaan penelitian ini tahun 2019 dengan nomor kontrak 07/PDP-

KEMENRISTEKDIKTI/PPPM/IV/2019.

\section{REFERENSI}

[1] Djauhari T. Gizi dan 1000 HPK. Saintika Med 2017;13. https://doi.org/10.22219/sm.v13i2.5554.

[2] Victora CG, Adair L, Fall C, Hallal PC, Martorel M, et al. Maternal Child Undernutrition consequences for adulth health and human capital. Lancet 2008;7:340-57.

[3] WHO. UNICEF-WHO-World Bank Joint Child Malnutrition Estimates. 2020.

[4] USAID. Multi-sectoral Nutrition Strategy 20142025 Technical Guidance Brief:Implementation Guidance for Ending Preventable Maternal and Child Death. 2014.

[5] Infodatin. Situasi Balita Pendek. Jakarta: 2016.

[6] Balitbankes. Riset Kesehatan Dasar 2018. Kementeian Kesehatan Republik Indonesia; 2018. n.d.

[7] Dinas Kesehatan Sleman. Prevalensi stunting di 
Kabupaten Sleman. Kabupaten Sleman;2018. n.d.

[8] Dinas Kesehatan Kota Yogyakarta. Prevalensi stunting di Kota Yogyakarta. Yogyakarta;2019. n.d.

[9] Bupati Sleman. Peraturan Bupati Sleman Nomor 21 Tahun 2019 tentang Program Percepatan Penanggulangan Balita Stunting. 2019.

[10] Hoddinott J. Adult consequences of growth failure in early childhood. Am J Clin Nutr 2013;98:1170-8. https://doi.org/10.3945/ ajcn.113.064584.

[11] Hoddinott J. The economic rationale for investing in stunting reduction. Mat Child Nutr 2013;9:69-82. https://doi.org/10.1111/ mcn.12080.

[12] Grantham-McGregor S. Developmental potential in the first 5 years for children in developing countries. Lancet 2007;369:60-70. https://doi.org/10.1016/S01406736(07)60032-4.

[13] Carba DB. Early childhood length-for-age is associated with the work status of Filipino young adults. Econ Hum Biol 2009;7:7-17. https://doi.org/10.1016/j.ehb.2009.01.010.

[14] Adair LS. Associations of linear growth and relative weight gain during early life with adult health and human capital in countries of low and middle income: findings from five birth cohort studies. Lancetancet 2013;382:525-34. https://doi.org/10.1016/S0140- 673.

[15] Prendergast AJ, Humphrey JH. The stunting syndrome in developing countries. Paediatr Int Child Health 2014;34:250-65. https://doi.org/10.1179/2046905514Y.00000 00158.

[16] WHO. Global Strategy on Infant and Young Child Feeding. Switzerland: 2013.

[17] Cai X, Wardlaw T, Brown DW. Global trends in exclusive breastfeeding. Int Breastfeed J 2012;7:12.

[18] Rusmil VK, Prahastuti TO, Luftimas DE, Hafsah T. Exclusive and Non-Exclusive Breastfeeding among stunted and Normal 6-9 Month-OldChildren in Jatinangor Subdistrict, Indonesia. AMJ 2019;6:35-41.

[19] Ballard 0, Morrow AL. Human milk composition: Nutrients and bioactive factors. Pediatr Clin North Am 2013;60:49-74.

[20] International Food Policy Research Institute. Global Nutrition Report 2014: Actions and Accountability to Accelerate the World's Progress on Nutrition. Washington (DC): 2014.
[21] Countries M, Martorell R, Horta BL, Adair LS, Stein AD, et al. Weight Gain in the First Two Years of Life Is an Important Predictor of Schooling Outcomes in Pooled Analyses from Five Birth Cohorts. J Nutr 2010;140:348-354.

[22] Aryastami NK, Shankar A, Kusumawardani N, Besral B, Jahari AB. Low birth weight was the most dominant predictor associated with stunting among children aged 12 - 23 months in Indonesia 2017:1-6. https://doi.org/10.1186/s40795-017-0130-x.

[23] Bisai S. Growth pattern and prevalence of underweight, stunting and wasting among infants of Kolkata, West Bengal, India. J Biol Anthr 2009;3.

[24] Kramer MS. Socioeconomic disparities in pregnancy outcome: why do the poor fare so poorly? Paediatr Perinat Epidemiol 2000;14:194-210.

[25] Kuchenbecker J, Jordan I, Reinbott A, Herrmann J, Jeremias T, Kennedy G, dkk. Exclusive breastfeeding and its effect on growth of Malawian infants: results from a cross-sectional study. Paediatr Int Child Health. 2015;35(1):1423. n.d.

[26] Rahayu NS, Nadhiroh K. Faktor yang berhubungan dengan kejadian stunting pada balita. Media Gizi Indones 2015;10:13-9.

[27] Barir B, Murti B, Pamungkasari EP. The Associations between Exclusive Breastfeeding, Complementary Feeding, and the Risk of Stunting in Children Under Five Years of Age: A Path Analysis Evidence from Jombang East Java. J Matern Child Heal 2019;4:486-98. https://doi.org/10.26911/thejmch.2019.04.06 .09 .

[28] Lestari ED, Hasanah F, Nugroho NA. Correlation between non-exclusive breastfeeding and low birth weight to stunting in children. Paediatr Indones 2018;58:123-7. https://doi.org/10.14238/pi58.3.2018.123-7.

[29] Uwiringiyimana V, Ocke MC, Amer S, Veldkamp A. Predictors of stunting with particular focus on complementary feeding practices: A crosssectional study in the northern province of Rwanda. Nutrients 2019;60:11-8.

[30] WHO. WHO global nutrition targets 2025: Stunting policy brief. Geneva: WHO; 2014.

[31] Rakotomanana H, Gates GE, Hildebrand D, Stoecker BJ. Situation and determinants of the infant and young child feeding (IYCF) indicators in Madagascar: Analysis of the 2009 demographic and health survey. BMC Public Health Journal. 2017; 17(812): 1-10. htt n.d.

[32] Udoh EE, Amodu OK. Complementary feeding practices among mothers and nutritional status 
of infants in Akpabuyo Area, Cross River State Nigeria. SpringerPlus. 2016; 5(2073):1-19. https:// doi.org/10.1186/s40064-016-3751-7 n.d.

[33] Adriani M, Wirjatmadi B. The effect of adding zinc to vitamin $A$ on IGF-1, bone age and lineargrowth in stunted children. J Trace Elem Med Biol 2014;28:431-5.
[34] Semba RD, Shardell M, Ashour FAS, Moaddel R, Trehan I, et al. Child stunting is associated with low circulating essential amino acids. Ebio Med 2016;6:246-52. 